\title{
A General Framework of Crime Determination and the Controversial Use of Crime in the Efficiency Analysis
}

\author{
Thyago Celso Cavalcante Nepomuceno
}

Universidade Federal de Pernambuco \& Sapienza Università di Roma thyago.nepomuceno@ufpe.br; nepomuceno@diag.uniroma1.it

\section{Citation Reference:}

Nepomuceno, T. C. C., Santiago, K. T. M.; Dario, C. \& Costa, A. P. C. S. (2020). Exogenous Crimes and the Assessment of Public Safety Efficiency and Effectiveness. Forth-coming issue in the Annals of Operations Research. doi: 10.1007/s10479-02003767-6

Using crime as an input has been reported in many assessments of police efficiency. The seminal application of Thanassoulis (1995) in the British police is the main instance. By using the occurrences of violent crimes, burglaries and other crimes as input to produce clear-up levels on these variables the author emphasizes potential weaknesses in the Police Forces, efficient peers and suggests higher labor associated with higher clear up efficiencies. Another empirical application following this avenue is provided by Verma \& Gavirneni (2006) measuring the police efficiency in India using the number of investigated crimes as input on the assumption that it forms the basis for subsequent investigation and prosecution. Property misdemeanors such as burglaries, thefts, robberies, raids, street mugging, vehicle robberies, and violent liferelated crimes are typical inputs found in many other performance evaluations e.g. Sun (2002), Barros (2007), Agdokan (2012), Drake \& Simper (2000; 2005) and Hadad, Keren \& Hanani (2015).

Despite the considerable relevance of these assessments in the Operational Research literature, crime cannot be considered as a discretionary resource because it cannot be directly controlled (reduced). According to Gaver \& Lehoczky (1987) crime is a stochastic process associated to a function of probability evolving over time with the existing dynamics on arrests and incarcerations. Many social, demographic, spatial and economic covariates not under the control of police stations work as positive determinants for the criminality. For this same reason, it cannot be considered as output from the production process. The Carrington, Puthucheary \& Rose (1997) assessment of the Australian Police Patrol in the New South Wales considering property offenses and car accidents as the output to measure the technical efficiency provides one of the many relevant applications in the field. Another interesting application comes from DeAngelo, Vitaliano \& Lang (2014) who considered the inverse of the violent crime rate per capita and property crime per capita as outputs produced by 50 municipal police departments in New York to infer some factors impacting the police productivity (community policing officers, employment, computers).

Similar production setups can be observed with the selection of variables by García-Sánchez (2008) concerning the number of accident reports, Rahimi, et al. (2017) considering car crashes and many other assessments such as Nyhan \& Martin (1999), García-Sánchez (2007), Barros \& Alves (2005), Gorman \& Ruggiero (2008), 
$\mathrm{Wu}$, Chen \& Yeh (2010). Table 1 summarizes the production structure configuration for some selected assessments of police performance using the crime data as input or output. Because the stochastic nature of the criminal incidence, it is always possible to assume an increase in the police technical efficiency (e.g. by increase the number of solved cases) and still have a more than proportional increase in the criminal incidence regardless how productive the police were. Thus, an efficiency analysis of police units can never rely on an investigation of crime as output (Ostrom 1973).

Table 1. Selected Literature on Police Efficiency Assessments

\begin{tabular}{|c|c|c|c|}
\hline Publication & DMUs & Inputs & Outputs \\
\hline $\begin{array}{c}\text { Thanassoulis } \\
\text { (1995) }\end{array}$ & $\begin{array}{l}41 \text { British police } \\
\text { forces in England } \\
\text { and Wales }\end{array}$ & $\begin{array}{l}\text { Police Personal (officers); } \\
\text { Violent Crimes; burglaries; } \\
\text { Other crimes }\end{array}$ & $\begin{array}{c}\text { Violent Crimes Clear-ups; } \\
\text { Burglaries Clear-ups; Other } \\
\text { Crimes Clear-ups }\end{array}$ \\
\hline $\begin{array}{l}\text { Carrington, } \\
\text { Puthucheary } \\
\text { \& Rose (1997) }\end{array}$ & $\begin{array}{l}163 \text { Patrol units in } \\
\text { New South Wales } \\
\quad \text { (Australia) }\end{array}$ & $\begin{array}{l}\text { Police Officers, Civilian } \\
\text { Employees; Capital } \\
\text { Equipment }\end{array}$ & $\begin{array}{c}\text { Offences; Arrests; } \\
\text { Summons; Car accidents; } \\
\text { Kilometers travelled by } \\
\text { police cars }\end{array}$ \\
\hline $\begin{array}{l}\text { Gorman \& } \\
\text { Ruggiero } \\
(\mathbf{2 0 0 8})\end{array}$ & 49 US states & $\begin{array}{c}\text { Police officers, } \\
\text { Other employees; } \\
\text { Vehicles }\end{array}$ & $\begin{array}{l}\text { Murders; Other Violent } \\
\text { Crimes; Property Crimes }\end{array}$ \\
\hline $\begin{array}{c}\text { Nyhan \& } \\
\text { Martin (1999) }\end{array}$ & $\begin{array}{l}25 \text { Local } \\
\text { Governments (US) }\end{array}$ & $\begin{array}{l}\text { Police staff (FTE); } \\
\text { Department cost }\end{array}$ & $\begin{array}{c}\text { Violent and Property Crimes } \\
\text { Clear-ups; } \\
\text { Response Time; } \\
\text { Crime Rate; }\end{array}$ \\
\hline $\begin{array}{c}\text { Drake and } \\
\text { Simper }(\mathbf{2 0 0 0})\end{array}$ & $\begin{array}{l}35 \text { British police } \\
\text { forces in England } \\
\text { and Wales }\end{array}$ & $\begin{array}{l}\text { Employment cost } \\
\text { Premises-related expenses } \\
\text { Transport-related expenses } \\
\text { Capital and other expenses }\end{array}$ & $\begin{array}{l}\text { Traffic offenses; } \\
\text { Crime Clear-ups }\end{array}$ \\
\hline $\begin{array}{c}\text { Drake and } \\
\text { Simper (2005) }\end{array}$ & $\begin{array}{l}41 \text { British police } \\
\text { forces in England } \\
\text { and Wales }\end{array}$ & $\begin{array}{l}\text { Burglaries; Motor Vehicle } \\
\text { Robberies; Budget }\end{array}$ & $\begin{array}{c}\text { Civilian days lost; } \\
\text { Aggregate Crimes Clear-ups }\end{array}$ \\
\hline $\begin{array}{l}\text { Verma and } \\
\text { Gavirneni } \\
(\mathbf{2 0 0 6}) \\
\end{array}$ & 25 states (India) & $\begin{array}{l}\text { Expenditure; Police officers; } \\
\text { Investigating officers; } \\
\text { Investigated Crimes }\end{array}$ & $\begin{array}{c}\text { Persons arrested; Persons } \\
\text { charge sheeted; Persons } \\
\text { convicted; Trials completed }\end{array}$ \\
\hline Barros (2007) & $\begin{array}{l}33 \text { Lisbon police } \\
\text { precincts over } 3 \\
\text { years (99 } \\
\text { observations) }\end{array}$ & $\begin{array}{l}\text { Police officers; Cost of labor; } \\
\text { Vehicles per precinct; Other } \\
\text { costs; Thefts; Number of } \\
\text { burglaries; Car robberies; } \\
\text { Drug-related Crimes }\end{array}$ & $\begin{array}{c}\text { Theft Clear-ups; } \\
\text { Burglaries Clear-ups; Stolen } \\
\text { cars Clear-ups; Drug-related } \\
\text { crimes Clear-ups; Police } \\
\text { raids; Number of stop } \\
\text { operations; Minor offenses }\end{array}$ \\
\hline $\begin{array}{l}\text { Aristovnik, } \\
\text { Seljak \& } \\
\text { Mencinger, } \\
\text { (2014) }\end{array}$ & $\begin{array}{c}76 \text { Police } \\
\text { organizations in } \\
\text { Slovenia }\end{array}$ & $\begin{array}{l}\text { Posts occupied; Work } \\
\text { stations; Police vehicle radio } \\
\text { stations; Criminal offences*; } \\
\text { Violations of public order } \\
\text { regulations*; Road accidents* }\end{array}$ & $\begin{array}{l}\text { Crime Clear-ups; Road } \\
\text { accidents (serious injury and } \\
\text { minor injury); Average } \\
\text { response time of police } \\
\text { patrols; Usage of } \\
\text { instruments of restraint and } \\
\text { warning shots }\end{array}$ \\
\hline $\begin{array}{l}\text { Hadad, Keren } \\
\text { \& Hanani } \\
(\mathbf{2 0 1 5})\end{array}$ & $\begin{array}{l}13 \text { police stations } \\
\text { in the south of } \\
\text { Israel over } 4 \text { years } \\
\text { (52 observations) }\end{array}$ & $\begin{array}{c}\text { Property crimes; Violent } \\
\text { crimes; Burglaries; Traffic } \\
\text { accidents; Traffic accidents } \\
\text { with injuries. Personnel and } \\
\text { operational costs; Population } \\
\text { size; Vehicles }\end{array}$ & $\begin{array}{l}\text { Property crimes Clear-up } \\
\text { rates; Drunken driving cases } \\
\text { exposed; Traffic reports }\end{array}$ \\
\hline
\end{tabular}

*Non-discretionary Inputs 
The criminal occurrences for a specific region or period are influenced by exogenous determinants, which (at the short run) cannot be controlled directly or are difficult to manage. The Nobel laureate Professor Elinor Ostrom (1973) proposed a general framework for the propensity of individuals toward unruled strategies that jeopardize the security of the community. An adaptation for this model on property offenses is illustrated in the Figure 1. According to Ostrom, population characteristics such as income, social status, educational attainment, religious preference, density, social status, age, home ownership, race and ethnicity are social-economic and demographic indicators of how well institutional arrangements such as the employment, product, housing market, educational, court, penal and welfare systems and the community organization have operated in the past (long-run). The lower the level on those indicators, the higher the propensity of individuals within the community to pursue the criminality.

The decision-making toward crime described by the framework in the Figure 1 can be conceptualized as social interactions mediated by multiple institutional arrangements that are not under the control of the police unit. Notwithstanding, police is one of these many arrangements. The individuals with sufficient propensity to delinquency are represented in the middle of this framework. In this case, there are three main triggers for a prone individual to get involved in the criminal conduct: the opportunity, the expected value, and the necessity. Only one of these triggers is sufficient to ignite the misdemeanor, given the operating circumstances. A distracted passerby, the lack of policing or the lack of appropriate attention on personal belongings can be characterized as opportunities for a prone individual to engage in property misdemeanors when they do not present high expected value or necessity for this strategy. The expected value for the crime is defined under the rational choice perspective of the economist and Nobel laureate Gary Becker (1968). The prone individual's decision to pursue the offense is made when the expected utility from engaging in the criminal activity is positive, i.e. the expected gains are sufficiently high to compensate the expected loss (in terms of the probability of punishment). Likewise, in this case the decision toward crime can be made even when the necessity or opportunity are not favorable.

The last trigger for criminality in prone individuals refers to the necessity to subtract the property of others. Critical poverty scenarios encourage a rational individual to irrational decisions, such as to commit the crime when the probability of being caught, exposed and convicted is high (low expected value) or when the circumstances are not favorable (low opportunity). While only one trigger is sufficient to ignite the desire toward the property offense, given the operating circumstances, low levels in all of them are required for a prone individual to restrain from committing the offense. Naturally, many individuals who despite the opportunity, the expected value and the necessity, will not lean upon delinquency. In the Ostrom (1973) perspective, those are individuals with considerable levels of education attainment, higher age, status, income, religious and political doctrines. Thus, cannot be characterized as individuals prone to crime in the decision model of the Figure 1. 
Figure 1. General Framework of Crime Determination

Adapted from Ostrom (1973) Output Model for the Security of the Community

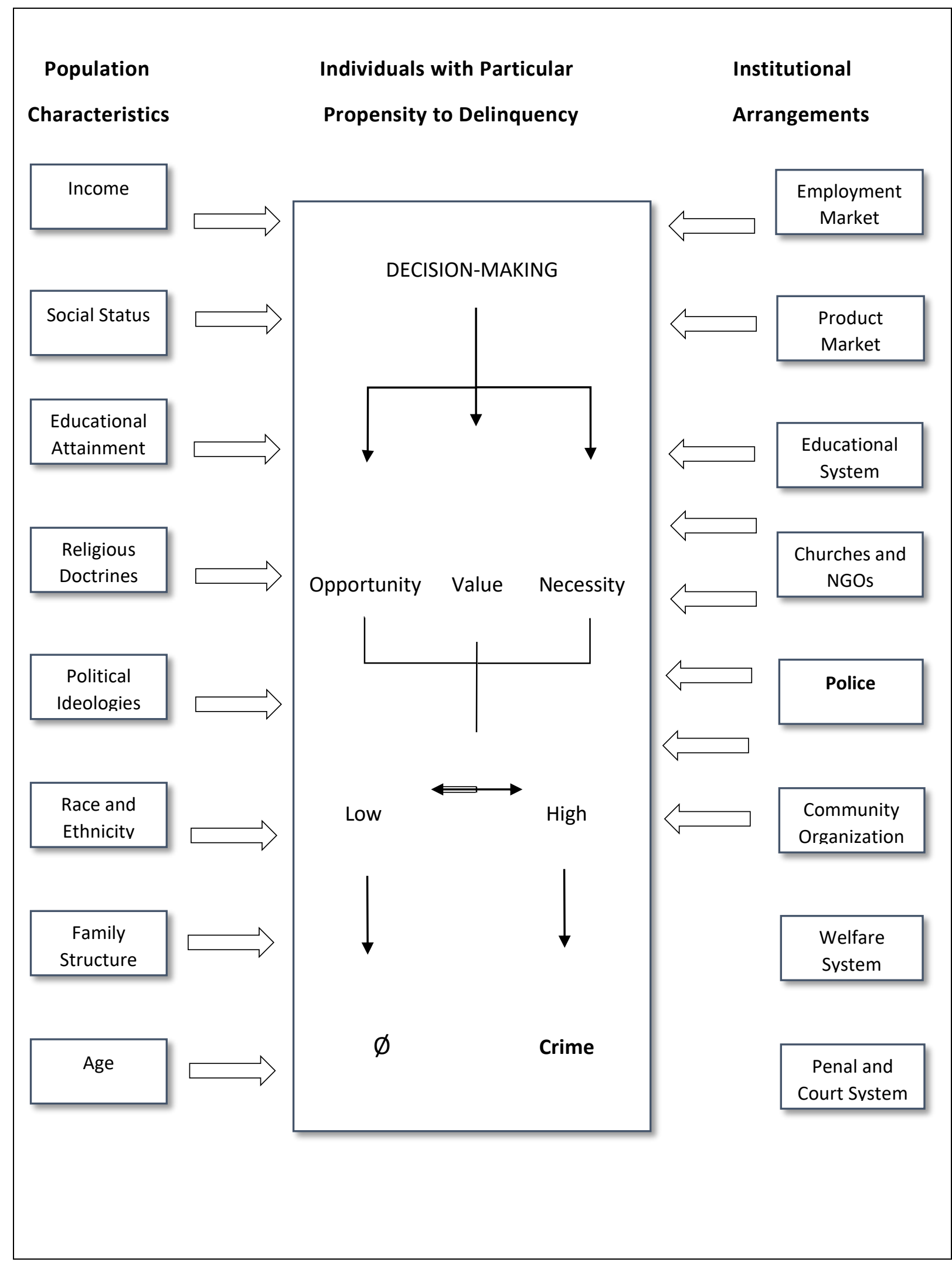


These listed population covariates, besides not being under the control of police units, they cannot be sufficiently enhanced or coherently measured in the short-run, making it impossible to predict a reduction in the criminal input or an expansion in the security of the community. In Brazil, one of the most well deemed state-level programs in the prevention of homicides is the so-called Pacto pela Vida (A Pact for Life), executed in many northern regions of the country (Ratton, Galvão \& Fernandez 2014; Ratton \& Daudelin 2018). Today is of common knowledge from empirical evidence that some of the good prospects in reducing the criminal behavior can be attributed to the country's long-term favorable economic stability. Despite the increasing efforts from the recent administrations, crime has come to increase with the increase in the unemployment rate.

If it were possible to trace every single aspects and determinants in modelling the criminal behavior, an efficiency measure for the police performance, using crime as discretionary input or output would still be potential biased by the correlation and dependence on other results. Asmild et al. (2011) using Pastor and Sirvent (2002) statistical test for nested radial frontier models exemplifies this assertion. The authors divided a sample with 16 police units in three main production functions in order to investigate the police performance: an enforcement model, a response to emergency model and a crime prevention model. Each model shares the same resource (labor in full time equivalent measure) to produce different results. After performing further analysis for the third model, the authors opt to remove the inverse crime rate from the assessment for being redundant in view of the fact that this variable can be returned as a consequence from the other two considered outputs (time on patrol and the number of times people are stopped and interviewed).

The problem with efficiency assessments based on criminal data as input and output is also acknowledged by some interesting application such as Diez-Ticio \& Mancebon (2002) investigating 47 Spanish Police Forces using Police officers and vehicles as inputs and clear-ups as outputs; Domínguez et al. (2015) using panel data on police efficiency and exogenous probabilities; and Barros (2007) who discuss the subject with data provided by the Policía Nacional Civil in Guatemala. The last author suggests two potential solutions to this problem. The first is the exclusion of the external crimes outside the control of police management in order to decrease the degree of bias in the inefficiency distribution. The second is to include the uncontrollable criminality and investigate the significance of the bias thought comparing efficiencies scores with and without the external factors. As acknowledge by the author, removing important data from the analysis limits the potential prospects from the results. In addition, including environmental uncontrollable factors as input does not guarantee the consistency of the results. Nevertheless, the author opts for the exclusion of uncontrollable inputs from the efficiency analysis.

An alternative to the exclusion of crime data from the analysis is considered by Aristovnik, Seljak \& Mencinger (2014) in the assessment of 76 Police organizations in Slovenia. The authors use as inputs the number of posts occupied, work stations, police vehicle radio stations and include the occurrences of criminal offences, violations of public order regulations and road accidents as non-discretionary inputs in the production technology. By restricting the reference set and the variables that are active in the decomposition of the technical efficiency measures, or by imposing a directional vector equal to 0 (zero), non-discretionary models and models for 
undesirable data are able of controlling for fixed resources that cannot be reduced or negative outputs that should not be increased, such as externalities.

As highlighted by Verma \& Gavirneni (2006), one of the fundamental aims for the police enforcement is to prevent crimes, but it is impossible to measure the number of crimes that have been prevented, only those that have been solved. This discussion is important to highlight the essential argument for crime to be considered as an external factor or as a non-discretionary variable in the efficiency analysis of police performance at the short-run. Strong public policies such as strict jail sentences, incentives for social inclusion, income and educational attainments, can provide a disincentive to committing crime. Still, it is extremely difficult to attribute these public policies to the performance of a specific police station, and it is difficult to perceive the effects of these policies at the short-run reduction of crime.

Other interesting studies of the criminal behavior in Pernambuco can be accessed in Nepomuceno \& Costa (2019) and Nepomuceno et al. (2017).

\section{REFERENCES}

Agdokan, H. (2012). The efficiency of police stations in the city of Ankara: an application of data envelopment analysis. Policing: An International Journal of Police Strategies \& Management, Vol. 35 No. 1, pp. 25-28.

Aristovnik, A., Seljak, J., \& Mencinger, J. (2013). Relative efficiency of police directorates in Slovenia: A non-parametric analysis. Expert Systems with Applications, 40(2), 820-827.

Aristovnik, A., Seljak, J., \& Mencinger, J. (2014). Performance measurement of police forces at the local level: A non-parametric mathematical programming approach. Expert Systems with Applications, 41(4), 1647-1653.

Asmild, M., Paradi, J. C., \& Pastor, J. T. (2011). DEA based models for reallocations of police personnel. OR Spectrum, 34(4), 921-941. doi:10.1007/s00291-0110243-6

Barros, C. P., \& Alves, F. P. (2005). Efficiency in crime prevention: A case study of the Lisbon precincts. International Advances in Economic Research, 11(3), 315328.

Barros, C.P. (2007). The city and the police force: analysing relative efficiency in city police precincts with data envelopment analysis, International Journal of Police Science \& Management, Vol. 9 No. 2, pp. 164-182.

Becker, G. S. (1968). Crime and punishment: An economic approach. In The economic dimensions of crime (pp. 13-68). Palgrave Macmillan, London.

Carrington, R., Puthucheary, N. e Rose, D., (1997), Performance measurement in government service provision: the case of police services in New South Wales, Journal of Productivity Analysis, 8, 415-430. 
DeAngelo, G., Vitaliano, D. F., \& Lang, H. (2014). Crime Rates and Police Efficiency. Eastern Economic Journal, 40(4), 535-559.

Diez-Ticio, A. \& Mancebon, M. J. (2002). The efficiency of the Spanish police service: an application of the multiactivity DEA model, Applied economics, 34 (3), 351-362.

Domínguez, J. P., Sánchez, I. M. G., \& Domínguez, L. R. (2015). Relationship between police efficiency and crime rate: a worldwide approach. European Journal of Law and Economics, 39(1), 203-223.

Drake, L e Simper, R. (2003), The measurement of English and Welsh police force efficiency: A comparison of distance function models, European Journal of Operational Research, 147 (1), 165-186.

Drake, L e Simper, R., (2000), Productivity estimation and size-efficiency relationship in English and Welsh police forces: An application of data envelopment analysis and multiple discriminant analysis, International review of law and economics, 20(1), 53-73.

Drake, L. M., \& Simper, R. (2005). The measurement of police force efficiency: an assessment of UK Home Office policy. Contemporary Economic Policy, 23(4), 465-482.

García-Sánchez, I. M. (2007). Evaluating the effectiveness of the Spanish police force through data envelopment analysis. European Journal of Law and Economics, 23(1), 43-57.

García-Sánchez, I.-M. (2008). Measuring the efficiency of local police force. European Journal of Law and Economics, 27(1), 59-77. doi:10.1007/s10657-0089079-1

Gaver, D. P., \& Lehoczky, J. P. (1987). Statistical analysis of hierarchical stochastic models: Examples and approaches. Annals of Operations Research, 8(1), 217227.

Gorman, M. F., \& Ruggiero, J. (2008). Evaluating US state police performance using data envelopment analysis. International Journal of Production Economics, 113(2), 1031-1037.

Hadad, Y., Keren, B., \& Hanani, M. Z. (2015). Combining data envelopment analysis and Malmquist Index for evaluating police station efficiency and effectiveness. Police Practice and Research, 16(1), 5-21.

Nepomuceno, T. C. C., \& Costa, A. P. C. S. (2019). Spatial visualization on patterns of disaggregate robberies. Operational Research, 1-30.

Nepomuceno, T. C. C., de Moura, J. A., e Silva, L. C., \& Costa, A. P. C. S. (2017). Alcohol and violent behavior among football spectators: An empirical assessment of Brazilian's criminalization. International journal of law, crime and justice, 51, 34-44. 
Nyhan, R. C., \& Martin, L. L. (1999). Assessing the performance of municipal police services using data envelopment analysis: an exploratory study. State and Local Government Review, 31(1), 18-30.

Ostrom, E. (1973). On the meaning and measurement of output and efficiency in the provision of urban police services. Journal of Criminal Justice, 1(2), 93111.doi:10.1016/0047-2352(73)90091-3

Pastor, J. T., Ruiz J. L., Sirvent I. (2002). A statistical test for nested radial DEA models. Oper Res 50(4):728-735

Rahimi, H., Soori, H., Nazari, S. S. H., Motevalian, S. A., Azar, A., Momeni, E., \& Javartani, M. (2017). The relative efficiency of Iranian's rural traffic police: a three-stage DEA model. BMC Public Health, 17(1). doi:10.1186/s12889-0174780-z

Ratton, J. L., \& Daudelin, J. (2018). Construction and deconstruction of a homicide reduction policy: the case of pact for life in Pernambuco, Brazil. International Journal of Criminology and Sociology, 7, 173-183.

Ratton, José; Galvão, Clarissa; Fernandez, Michelle (2014). Pact for Life and the Reduction of Homicides in the State of Pernambuco. Stability: International Journal of Security and Development, 3(1).

Sun, S. (2002). Measuring the relative efficiency of police precincts using data envelopment analysis, Socio-Economic Planning Sciences, Vol. 36 No. 1, pp. 51 71.

Thanassoulis, E. (1995). Assessing police forces in England and Wales using data envelopment analysis. European Journal of Operational Research, 87(3), 641657.

Verma, A., \& Gavirneni, S. (2006). Measuring police efficiency in India: an application of data envelopment analysis. Policing: An international journal of police strategies \& management, 29(1), 125-145.

Wu, T.-H., Chen, M.-S. and Yeh, J.-Y. (2010), "Measuring the performance of police forces in Taiwan using data envelopment analysis", Evaluation and Program Planning, Vol. 33 No. 3, pp. 246-254. 